\title{
Oceanic pelagic prey of benthopelagic fish in the benthic boundary layer of a marginal oceanic region
}

\author{
John Mauchline, John D. M. Gordon \\ Scottish Marine Biological Association, PO Box 3, Oban, Argyll PA34 4AD, Scotland
}

\begin{abstract}
The availability of oceanic plankton and micronekton to the benthopelagic fish assemblages on the slopes of the Rockall Trough, a marginal region of the northeast Atlantic deep-sea environment, is examined. The vertical distribution of pelagic species predated by the fish was determined in the off-slope water column. as were the depths at which they are predated by the fish in the benthic boundary layer of the slope. The benthopelagic fish predated pelagic species at depths on the slope corresponding to the daytime depths of the pelagic prey. The occurrence of these pelagic species at the benthic boundary layer is primarly through truncation of their pelagic vertical distributions rather than horizontal impingement, although this does occur; this applies not only to epi- and mesopelagic but also to the bathypelagic species which can even reach abyssal sediments. Diel vertical migration of the pelagic species did not make them available to slope fishes in shallower depths presumably because vertical migration is strictly upwards within the pelagic water column and not up the contours of the slope sediment.
\end{abstract}

\section{INTRODUCTION}

The associations of organisms living immediately above the sea bed are referred to as suprabenthic (Brunel 1979, Kaartvedt 1989), hyperbenthic (Anger \& Valentin 1976, Hesthagen \& Gjermundsen 1978), or hypoplanktonic (Mauchline 1972) in coastal and shelf regions. These associations contain endemic species resident in the near-bottom environment, species derived from downward extensions, often seasonal in nature, of pelagic planktonic populations, as well as infaunal species emerging into the water column, often on diel cycles. The top-level predators in these systems are, of course, the demersal fish associations.

Analogous associations are now known to inhabit the near-bottom environment of the deep-sea where they are usually referred to as the benthopelagic fauna (Marshall \& Merrett 1977). Wishner and her colleagues have examined this fauna in some detail (Wishner 1980a, b, c, Wishner \& Meise-Munns 1984, Gowing \& Wishner 1986, Wishner \& Gowing 1987). They refer to this environment as the benthopelagic or benthic boundary layer, as do Childress et al. (1989). It has its own endemic fauna, phylogenetic aspects of which have been partially examined (Grice \& Hulsemann
1970. Grice 1972, Wishner 1980c, Hargreaves 1984 1985, Hargreaves et al. 1984, Domanski 1986, Gowing \& Wishner 1986, Childress et al. 1989). These studies are linked to those of benthopelagic coupling reviewed by Angel (1984, 1990), Deuser (1986) and Fowler \& Knauer (1986). Rapid sedimentation of phytoplankton to the ocean bottom has been recently documented by Rice et al. (1986). Hecker (1990) and Thiel et al. (1990) and evidence of its direct utilization by component species of the benthos obtained (Gooday \& Lambshead 1989, Graf 1989). Some attention has centred on the episodic descent of large lumps of organic matter as instanced by nectonic carcases (Stockton \& DeLaca 1982. Smith 1985). Little attention, however, has been paid to impingement horizontally on to the slope, in marginal oceanic regions, of species of plankton and micronekton, nor of the downward extensions of pelagic populations making them directly available to predators such as the benthopelagic fish. Merrett (1986) reviewed the occurrence of micronektonic fish in the stomachs of demersal fish, noting records of 24 species representing 10 families of meso- and bathypelagic fishes.

Fraser $(1961,1968,1969)$ and Hopkins et al. (1981) examined the on-shelf or landward distribution of 
oceanic plankton and micronekton, while Hargreaves (1984, 1985) and Hargreaves et al. (1984) described the occurrence of species of micronekton, in the vertical water column and in the near-bottom environment of an adjacent slope region by using conventional multiple Rectangular Midwater Trawls. The present investigation supplements the current information on constitution and occurrence of the benthopelagic fauna. It examines the occurrence of micronektonic and planktonic species in the stomach contents of demersal fish in different bathymetric horizons between 400 and $3000 \mathrm{~m}$ depth on the slope of the Rockall Trough relative to their bathymetric occurrence in the oceanic water column adjacent to the slope.

\section{MATERIALS AND METHODS}

A vertical series of samples was collected at Stn 10105 at $54^{\circ} 30^{\prime} \mathrm{N}, 13^{\circ} \mathrm{W}$ in August/September 1979 using a multiple Rectangular Midwater Trawl (RMT $8+1$ ) (Roe \& Shale 1979, Roe et at. 1980). Samples were collected from $100 \mathrm{~m}$ depth strata between the surface and $900 \mathrm{~m}$ depth by both day and night to determine the extent of any diel migration of species. The influence of downwelling daylight was assumed to be absent at depths greater than $900 \mathrm{~m}$ where there would then be no significant diel vertical migration of species (Angel et al. 1982). Deeper samples were, therefore, collected at $200 \mathrm{~m}$ depth intervals between 900 and $1900 \mathrm{~m}$ irrespective of day or night. A full description of the sampling procedure at this station is given by Hargreaves et al. (1984). A comparison of the sampling efficiencies of the RMT 1 and 8 nets showed that the RMT 1 was more efficient for organisms of body volume less than $0.12 \mathrm{ml}$ (Mauchline 1989). This was true for all euphausiids, mysids except Gnathophausia zoea, and the small decapods Gen- nadas elegans, Sergestes arcticus and Hymenodora glacialis. The data used in this paper are from the RMT 1 samples.

The demersal fish were collected from the Hebridean Terrace and floor of the Rockall Trough in the area of 55 to $57^{\circ} \mathrm{N}, 9$ to $12^{\circ} \mathrm{W}$ at depths between 400 and $3000 \mathrm{~m}$. The discrete depth zones sampled are shown in Table 1 along with the numbers of species that consumed pelagic prey species and the corresponding numbers of their stomachs that contained food. The number of species without pelagic prey in their stomachs is given. Full descriptions of the trawls and fishing methods used are given by Gordon \& Duncan (1985, 1987) and Gordon (1986). The contents of each stomach were identified individually (Mauchline \& Gordon 1985, 1986, Gordon \& Mauchline 1990)

The bathymetric incidence of individual pelagic prey species has been examined in the following manner. The numbers of individuals of each pelagic prey species occurring in the stomachs of each predatory species of fish in each bathymetric horizon were listed. Each pelagic prey species was then examined separately and the numbers of stomachs, with food present, of its predatory species of fish were listed for each bathymetric horizon irrespective of whether the predatory species consumed that pelagic species in every horizon in which it occurred. The numbers of the pelagic species that occurred per 100 stomachs with food in each horizon were determined.

\section{RESULTS}

The prey species have been grouped according to their bathymetric occurrence in the pelagic water column and whether or not they perform a diel vertical migration. Epipelagic and mesopelagic vertical migrators are shown in Fig. 1. These species perform a diel

Table 1. Abundance of fish species predating pelagic organisms. Numbers of species and individuals with pelagic food present in the different benthopelagic depth honzons are given along with the corresponding numbers of species that did not consume pelagic prey

\begin{tabular}{|c|c|c|c|}
\hline $\begin{array}{l}\text { Depth horizons } \\
\text { (m) }\end{array}$ & $\begin{array}{c}\text { No. of species consuming } \\
\text { pelagic prey }\end{array}$ & $\begin{array}{l}\text { No. of stomachs } \\
\text { with food }\end{array}$ & $\begin{array}{c}\text { No. of species not } \\
\text { consuming pelagic prey }\end{array}$ \\
\hline $415-575$ & 12 & 482 & 29 \\
\hline $595-860$ & 25 & 1680 & 14 \\
\hline $816-1083$ & 30 & 1830 & 3 \\
\hline $1185-1296$ & 26 & 427 & 5 \\
\hline $1420-1536$ & 16 & 230 & 18 \\
\hline $1725-1890$ & 11 & 160 & 16 \\
\hline $1940-2045$ & 12 & 109 & 1 \\
\hline $2170-2300$ & 12 & 197 & 4 \\
\hline $2400-2565$ & 12 & 142 & 6 \\
\hline $2880-2975$ & 7 & 151 & 2 \\
\hline
\end{tabular}


vertical migration at night, the epipelagic species entering the extreme surface layers from a daytime depth range of ca 100 to $500 \mathrm{~m}$. Mesopelagic species rarely enter the surface $100 \mathrm{~m}$ of the water column from a daytime depth of about 300 to $800 \mathrm{~m}$. All species in Fig. 1 are predated from their daytime modal depths.

The species in Fig. 2 are characterized by their exploitation at depths on the slope deeper than their modal depths in the oceanic water column. The data for salps are not explicit in Fig. 2. Salps could not be counted in RMT 1 or 8 samples because they were so badly damaged (Hargreaves et al. 1984); hence the data on their vertical distribution in the water column is

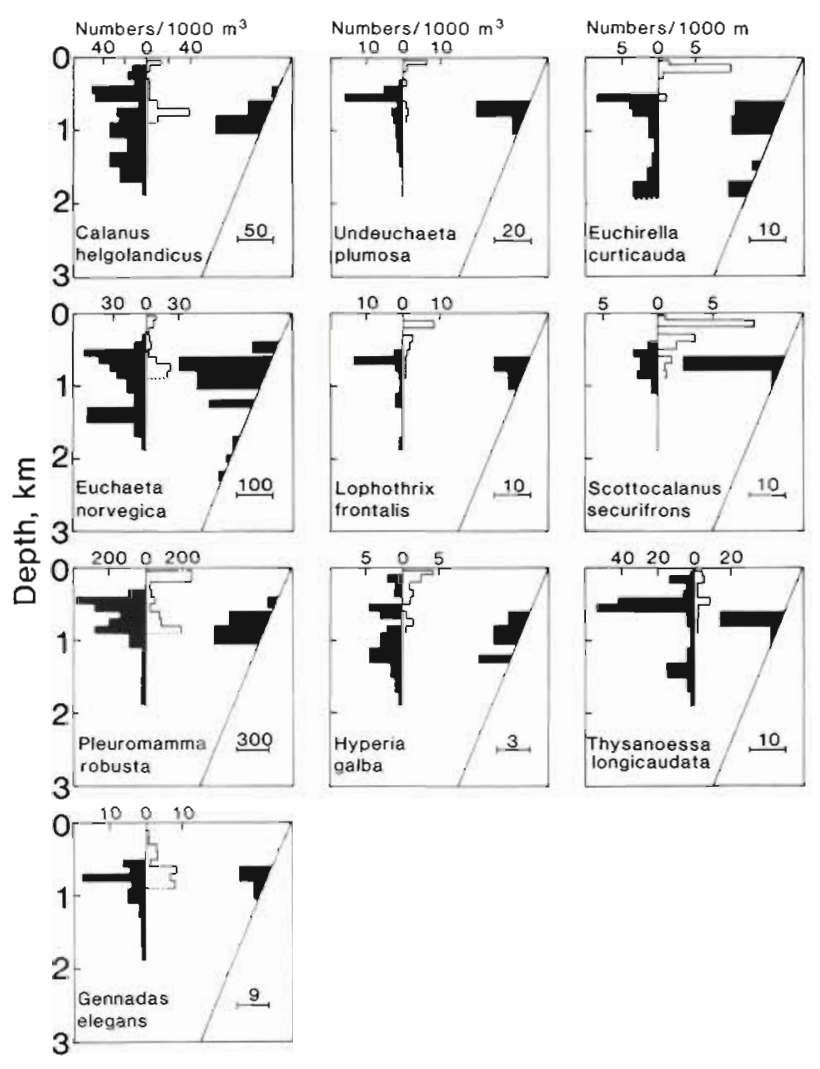

Fig. 1. Epipelagic and mesopelagic migrators: their vertical distribution in the oceanic water column (left) and their exploitation by the fish assemblages on the slope of the Rockall Trough (right). Their vertical distribution in the water column was determined from RMT 1 samples collected at $100 \mathrm{~m}$ depth intervals by day (shaded bars) and night (open bars) in the upper $900 \mathrm{~m}$ of the water column, and at $200 \mathrm{~m}$ depth intervals below $900 \mathrm{~m}$ (shaded) irrespective of day or night, at Stn 10105 in the Rockall Trough. Their incidence, number per 100 fish stomachs with food (denoted by the bar to the lower right of each figure), was determined for each bathymetric horizon of the slope as described in the text. Species are the calanoid copepods Calanus helgolandicus through to Pleuromamma robusta, the hyperiid amphipod Hyperia galba, the euphausid Thysanoessa longicaudata and the decapod Gennadas elegans. The incidence of species in the water column is given as number per $1000 \mathrm{~m}^{3}$ of water filtered
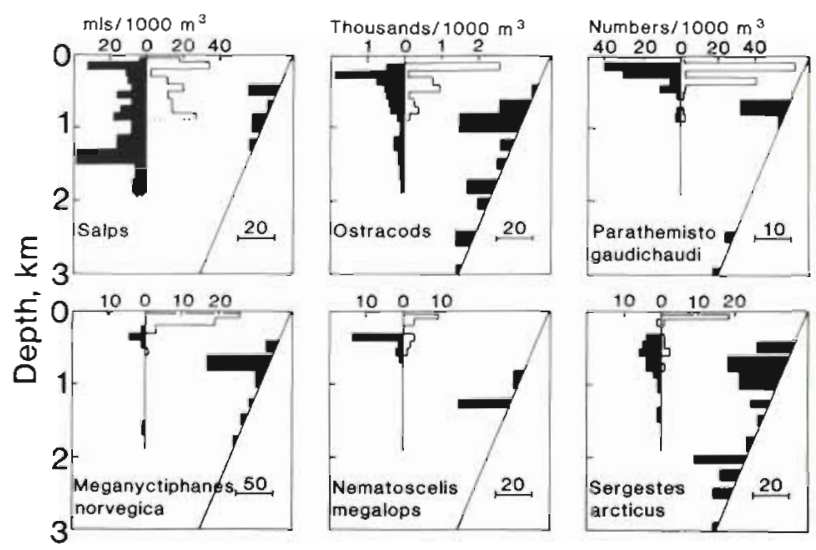

Fig. 2. Additional epipelagic and mesopelagic migrators: their vertical distribution in the oceanic water column (left) and their exploitation by the fish assemblages on the slope of the Rockall Trough (right) as defined in the legend to Fig. 1. Salps and ostracods were not identified to species. The other graphs are for the hyperiid amphipod Parathemisto gaudichaudi, the euphausiids Meganyctiphanes norvegica and Nematoscelis megalops, and the decapod Sergestes arcticus. With the exception of the 2 top left figures, all others are presented as number per $1000 \mathrm{~m}^{3}$ water filtered

presented as a volume measurement (Fig. 2). There is also considerable difficulty in positively identifying their remains in fish stomachs. Gordon \& Mauchline (1990) conclude that it is quite probable that much of the unidentified component of the diets of fish in the 800 to $1900 \mathrm{~m}$ depth horizons consists of coelenterates, salps and ctenophores. Swarms of salps have been reported in the Rockall Trough (Bathmann 1988) and would be expected to deposit on the sea bed, so becoming available to the slope fishes.

The conchoecid ostracods exploited below $1700 \mathrm{~m}$ depth probably reflect their pelagic occurrence below the maximum sampling depth of $1900 \mathrm{~m}$ of the vertical series. The amphipod Parathemisto gaudichaudi may be scavenged by the fish at $2500 \mathrm{~m}$ and deeper. The euphausiids Meganyctiphanes norvegica and Nematoscelis megalops and the decapod Sergestes arcticus appear, on impingement on the slope, to extend their lower vertical depth range and so be available to predatory fish at depths below $1000 \mathrm{~m}$.

Mesopelagic non-migrators (Fig. 3) occur in fish stomachs at depths corresponding to their vertical distribution in the oceanic water column. The distribution in the water column was determined from analysis of the RMT 1 samples but in the corresponding RMT 8 samples Boreomysis microps occurred to $1900 \mathrm{~m}$ while Meterythrops picta was caught in the 1300 to $1500 \mathrm{~m}$ sample (Hargreaves 1985). The euphausiid Thysanopoda acutifrons occurred in the deepest sample of the vertical series and its distribution therefore probably extends below $1900 \mathrm{~m}$ as also implied by the data of 
James (1987). Thus, there is no evidence of an extension of the lower vertical depth range of these species on impingement on the slope.

The vertical distributions of the bathypelagic species, which perform no diel vertical migration, extend below the lower sampling limit of the vertical series at $1900 \mathrm{~m}$ (Fig. 4). The only apparent exception is the mysid Gnathophausia zoea whose large size and relative rarity in the water column caused it to be inadequately sampled by the RMT nets. It occurs in epibenthic trawl samples from the Rockall Trough indicating its occurrence in the benthopelagic zone in significant numbers, as the data of Hargreaves (1985) also imply. The decapod Hymenodora glacialis rarely occurs above $1500 \mathrm{~m}$ in the pelagic water column and was found by Domanski (1986) to be the most abundant shrimp species within 10 to $25 \mathrm{~m}$ of the sea bed at depths of $4000 \mathrm{~m}$ south of Kings Trough centred at $41^{\circ} 30^{\prime} \mathrm{N}$, $30^{\circ} \mathrm{W}$. Its exploitation by the fish at $3000 \mathrm{~m}$ depth in the Rockall Trough must result from a similar vertical. distribution to that found by Domanski.

\section{DISCUSSION}

The pelagic prey species occurring in the stomachs of the benthopelagic fish assemblages are not necessarily the commonest or dominant species in the oceanic water column. Many of the epipelagic species live at depths that are too shallow to make them available to these fish. The prey must also be a certain minimum size and this precludes common crustacean plankton such as the cyclopoid copepods which only occurred in the diets of the smaller sized Alepocephalus bairdii and Coryphaenoides rupestris in small numbers (Mauchline \& Gordon 1983, 1984a).

What are the mechanisms that make these pelagic organisms available to the benthopelagic fish assemblages? Populations of epi- and mesopelagic species can extend vertically to the sediment surface, where their vertical distribution tends to become truncated, if the sediment is within the vertical range of the species. Consequently, the predation of fish of pelagic species in the benthopelagic regime at the daytime depths of the pelagic prey in the water column (Figs. 1 \& 3) does not necessarily involve horizontal impingement of these species on the slope. Their normal vertical distribution in the water column would make them available to the fish.

The same is true of bathypelagic species (Fig. 4). Domanski (1986) demonstrated an increase in abundance of decapod crustaceans in the benthopelagic layer within $100 \mathrm{~m}$ of the ocean bottom at depths of 4000 to $5500 \mathrm{~m}$. This undoubtedly reflects, as it does in coastal and shelf waters, a general increase in biomass

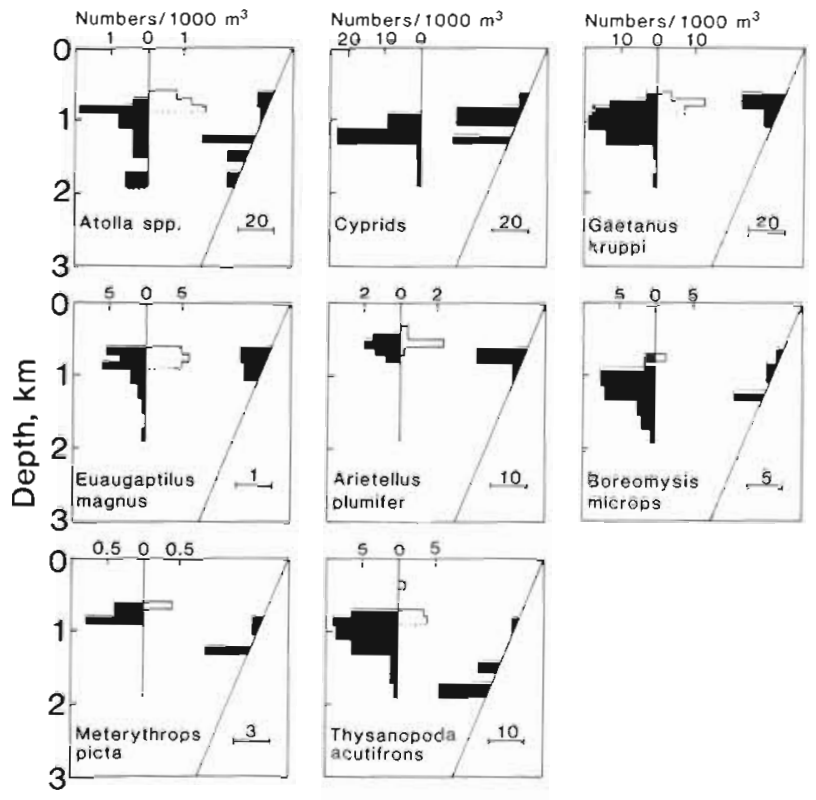

Fig. 3. Mesopelagic non-migrators: their vertical distribution in the oceanic water column (left) and their exploitation by the fish assemblages on the slope of the Rockall Trough (right) as defined in the legend to Fig. 1 . The 3 scyphomedusan species of the genus Atolla (see Mauchline \& Harvey 1983) were not separated. Cyprid larvae of barnacles were not identified. The other graphs are for the calanoid copepods Gaetanus kruppi, Euaugaptilus magnus and Arietellus plumifer, the mysids Boreomysis microps and Metervthrops picta, and the euphausiid Thysanopoda acutifrons

at this boundary layer relative to the water column immediately above it, as Wishner (1980a) found. Populations of many pelagic copepods, mysids, euphausiids and decapods have their lower vertical limits at the sediment surface in coastal, shelf and slope environments. The abyssal sediments are within range of the bathypelagic populations such as those of the decapod Hymenodora glacialis as demonstrated by Domanski (1986) and confirmed here.

There is, however, evidence of impingement through horizontal movement from the pelagic to benthopelagic environments in a few species (Fig. 2) These are the 2 euphausiids Meganyctiphanes norvegica and Nematoscelis megalops and the decapod Sergestes arcticus. Hargreaves (1984), sampling the benthopelagic slope environment with closing nets, found this downward extension of the distribution of $S$. arcticus in Porcupine Seabight immediately south of the Rockall Trough. $M$. norvegica is known to feed on the surface layers of the sediment in coastal environments (Maurhline \& Fisher 1969), as do presumably these other 2 species, but that does not explain the downward extension of the distribution below about $1500 \mathrm{~m}$.

Some species among the benthopelagic fish assemblages scavenge dead organisms that have sunk to the 


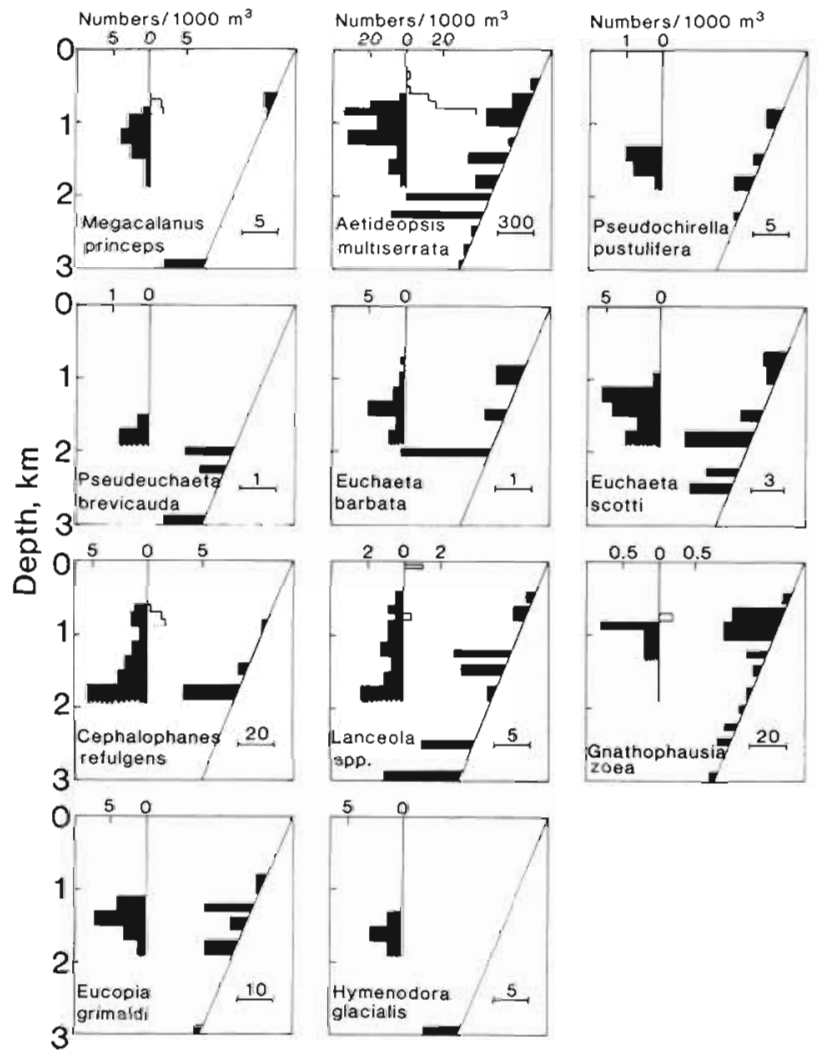

Fig. 4. Bathypelagic non-migrators: their vertical distribution in the oceanic water column (left) and their exploitation by the fish assemblages on the slope of the Rockall Trough (right) as defined in the legend to Fig. 1 The species are the calanoid copepods Megacalanus princeps through to Cephalophanes refulgens, unidentified amphipod species of the genus Lanceola, the mysids Gnathopausia zoea and Eucopia grimaldi, and the decapod Hymenodora glacialis

surface of the sediment. The blue whiting Micromesistius poutassou spawns in the surface $400 \mathrm{~m}$ of the Rockall Trough and occurred in the stomachs of Synaphobranchus kaupi, Histiobranchus bathybius, Nematonurus armatus and Antimora rostata at depths of 2200 to $2900 \mathrm{~m}$ in April in each of the 3 years in which samples were collected (Mauchline \& Gordon 1984b). The Parathemisto gaudichaudi and Sergestes arcticus recorded in fish stomachs at 2500 to $3000 \mathrm{~m}$ depth (Fig. 2) may have been scavenged. Both these pelagic species occurred in the stomachs of Nematonurus armatus. The $S$ arcticus recorded at 1700 to $2200 \mathrm{~m}$ had been eaten by $S$. kaupi in a strict seasonal window between the end of July and mid-September. Those occurring in the deeper $N$. armatus, at $2500 \mathrm{~m}$ depth, were present in the period mid-August to midOctober. The breeding season of $S$. arcticus probably extends to July or August in the Rockall Trough and a natural post-breeding mortality could be expected. It is the second most abundant decapod in the water column of the Trough, occurring in aggregations. Conse- quently, scavenging of these pelagic species may have given rise to their occurrence at these excessive depths.

Pelagic species are eaten by benthopelagic fish at depths corresponding to their daytime vertical distribution in the oceanic water column, or, in the case of a few species, at greater depths. Diel vertical migration into shallower regimes at night does not make them available to shallower assemblages of demersal fish presumably because such vertical migration is strictly into the pelagic domain and not up the contours of the slope sediment. The slope current travelling parallel to the shelf edge (Ellett et al. 1986) at depths down to about $800 \mathrm{~m}$ may restrict slopeward movement of the pelagic fauna and its subsequent transport on to the shelf. Fraser $(1961,1968,1969)$ records the occurrence of oceanic epipelagic species on the Scottish continental shelf but found that meso- and bathypelagic species occurred rarely. Hopkins et al. (1981) similarly found virtually no on-shelf transport of mesopelagic species in the west Florida region of the Gulf of Mexico, nor did Pearcy (1964) in the case of mesopelagic fish off the Oregon shelf. They suggested that even if these species migrated into the epipelagic and penetrated the onshelf waters, their survival there, through either predation or the lack of a vertical water column of sufficient depth to enable their lower daytime depth distribution, must be limited. This is also presumably true of impingement from their night-time depth on to the slope: predation and lack of depth in the water column will preclude colonisation in any numbers, or such that would register in fish diets.

Benthopelagic fish may migrate vertically into the water column to predate pelagic species. Haedrich (1974) caught 49 Coryphaenoides rupestris in midwater in the Denmark Strait: 37 of them were at least 250 to $500 \mathrm{~m}$ above the sea bed, a further 11 at least 660 to $710 \mathrm{~m}$ above, and one individual at least $1440 \mathrm{~m}$ above the bottom. These observations have never been repeated. Merrett et al. (1986) recorded C. rupestris, Halargyreus johnsonii and Synaphobranchus kaupi between 3 and $60 \mathrm{~m}$ above the bottom in the Rockall Trough but in small numbers. It is not known how frequently such pelagic excursions occur, nor whether they are short-term events, nor whether individual fish live in the water column for periods. The lack of data suggests that such excursions are rare or on a shorttime scale.

Demersal fish biomass is greatest between 800 and $1550 \mathrm{~m}$ depth, with a pronounced maximum at 1200 to $1300 \mathrm{~m}$ depth, on the slope of the Rockall Trough (Gordon \& Mauchline 1990). This corresponds to the depth range of greatest potential vertical and horizontal impingement of the epi- and mesopelagic fauna on the slope. The vertical impingement through the truncation of the vertical distribution of the species in the 
water column is probably the major factor involved in making this fauna available to benthopelagic fish assemblages in marginal oceanic regions and confirms the situation reported by Marshall \& Merrett (1977). The net northeastward flow of the water masses of the Trough in a shallowing environment (Mauchline 1990) must ensure that horizontal impingement of the fauna on the sides of the Trough is also active, probably most so at the northeastern, geographical limits of the Trough, south of the Wyville Thomson Ridge, an area that has not been sampled in this investigation.

Acknowledgements. We thank Dr M. V Angel and his colleagues of the Institute of Oceanographic Sciences, Wormley, for providing us with the vertical series of RMT 1 samples from the Rockall Trough. The Scottish Marine Biological Association is financed by the Natural Environment Research Council, Swindon.

\section{LITERATURE CITED}

Angel, M. V (1984). Detrital organic fluxes through pelagic ecosystems. In: Fasham, M. J. (ed.) Flows of energy and materials in marine ecosystems. Plenum, New York, p. $475-516$

Angel, M. V (1990). Life in the benthic boundary layer connections to the mid-water and sea floor Phil. Trans. R. Soc. Lond 331A: 15-28

Angel, M. V., Hargreaves, P. M., Kirkpatrick, P., Domanski, P. (1982). Low variability in planktonic and micronektonic populations at $1000 \mathrm{~m}$ depth in the v1cinity of $42^{\circ} \mathrm{N} 17^{\circ} \mathrm{W}$; evidence against diel migratory behaviour in the majority of species. Biol. Oceanogr 1: 287-319

Anger, K., Valentin, C. (1976). In situ studies on the diurnal activity pattern of Diastylis rathkei (Cumacea, Crustacea) and its importance for the 'hyperbenthos' Helgoländer wiss. Meeresunters. 38: 138-144

Bathmann, U. V (1988). Mass occurrence of Salpa fusiformis in the spring of 1984 off Ireland: implications for sedimentation processes. Mar Biol. 97. 127-135

Brunel, P. (1979). Seasonal changes of daily vertical migrations in a suprabenthic cold-layer shelf community over mud in the Gulf of St. Lawrence. In: Naylor, E., Hartnoll, R. G. (eds.) Cyclic phenomena in marine plants and animals. Pergamon Press, Oxford, p. 383-390

Childress, J. J., Gluck, D. L., Carney, R. S., Gowing, M. M. (1989). Benthopelagic biomass distribution and oxygen consumption in a deep-sea benthic boundary layer dominated by gelatinous organisms. Limnol. Oceanogr. 34: $913-930$

Deuser, W. G. (1986). Seasonal interannual vanations in deep water particle fluxes in the Sargasso Sea and their relation to surface hydrography. Deep Sea Res. 33: 225-246

Domanski, P. (1986). The near-bottom shrimp faunas (Decapoda: Natantia) at two abyssal sites in the Northeast Atlantic Ocean. Mar Biol. 93: 171-180

Ellett, D. J., Edwards, A., Bowers, R. (1986). The hydrography of the Rockall Channel-an overview. Proc. R. Soc. Edinb. 88B: 61-81

Fowler, S. W., Knauer, G. A. (1986). Role of Iarge particles in the transport of elements and organic compounds through the oceanic water column. Prog. Oceanogr. 16: 147-196

Fraser. J. H. (1961). The oceanic and bathypelagic plankton of the north-east Atlantic and its possible significance to fisheries. Mar Res, 4: 41-48

Fraser, J. H. (1968). The overflow of oceanic plankton to the shelf waters of the north-east Atlantic. Sarsia 34:313-330

Fraser, J. H. (1.969). Variability in the oceanic content of plankton in the Scottish area. Prog. Oceanogr 5: 149-159

Gooday, A. J., Lambshead, P. J. D. (1989). Influence of seasonally deposited phytodetritus on benthic foraminiferal populations in the bathyal northeast Atlantic: the species response. Mar Ecol. Prog. Ser. 58: 53-67

Gordon. J. D. M. (1986). The fish populations of the Rockall Trough. Proc. R. Soc. Edinb. 88B: 191-204

Gordon, J. D. M., Duncan, J. A. R. (1985). The ecology of the deep-sea benthic and benthopelagic fish of the slopes of the Rockall Trough, Northeastern Atlantic. Prog. Oceanogi 15: 37-69

Gordon, J. D. M., Duncan, J. A. R. (1987). Deep-sea bottomliving fishes at two repeat stations at 2200 and $2900 \mathrm{~m}$ in the Rockall Trough, northeastern Atlantic Ocean. Mar. Biol. 96: 309-325

Gordon, J. D. M., Mauchline, J. (1990). Depth-related trends in diet of a deep-sea bottom-living fish assemblage of the Rockall Trough. In: Barnes, M., Gibson, R. N. (eds.) Trophic relationships in the marine environment. University Press, Aberdeen, p. 439-452

Gowing, M. M., Wishner, K. F. (1986). Trophic relationships of deep-sea calanoid copepods from the benthic boundary layer of the Santa Catalina Basin, California. Deep Sea Res. 33: 939-961

Graf, G. (1989). Benthic-pelagic coupling in a deep-sea benthic community. Nature, Lond. 341. 437-439

Grice, G. D. (1972). The existence of a bottom-living calanoid copepod fauna in deep water with description of five new species. Crustaceana 23: 219-242

Grice, G. D., Hulsemann, K. (1970). New species of bottomluving calanoid copepods collected in deep water by the DSRV Alvin. Bull. Mus. comp. Zool. Harv. 139: 185-230

Haedrich, R. L. (1974). Pelagic capture of the epibenthic rattail Coryphaenoides rupestris. Deep Sea Res. 21: 977-979

Hargreaves, P. M. (1984). The distribution of Decapoda (Crustacea) in the open ocean and near-bottom over an adjacent slope in the northern north-east Atlantic Ocean during autumn 1979. J. mar biol. Ass. U.K. 64: 829-857

Hargreaves, P. M. (1985). The distribution of Mysidacea in the open ocean and near-bottom over slope regions in the northern North-east Atlantic Ocean during 1979. J. Plankton Res. 7: 241-261

Hargreaves, P. M., Ellis, C. J., Angel, M. V. (1984). An assessment of biological processes close to the sea bed in a slope region and its significance to the assessment of the sea bed disposal of radioactive waste. Institute of Oceanographic Sciences Report, Wormley 185: 1-117

Hecker, B. (1990). Photographic evidence for the rapid flux of particles to the sea floor and their transport down the contmental slope. Deep Sea Res. 37: 1773-1782

Hesthagen, I. H., Gjermundsen, B. (1978). The replicability of sampling in the hyperbenthic region by means of Beyer's $50 \mathrm{~cm}$ epibenthic closing net. Ber. dt. wiss. Kommn Meeresforsch. 27.1-10

Hopkins, T L., Milliken, D. M., Bell, L. M., McMichael, E. J., Heffernan, J. J. Cano, R. V (1981). The landward distribution of oceanic plankton and micronekton over the west Florida continental shelf as related to their vertical distribution. J. Plankton Res. 3: 645-658

James, P. T (1987). Euphausids of the north-east Atlantic. Institute of Oceanographic Sciences Report, Wormley 240 : $1-103$ 
Kaartvedt, S. (1989). Retention of vertically migrating suprabenthic mysids in fjords. Mar. Ecol. Prog. Ser. 57: 119-128

Marshall, N. B., Merrett, N. R. (1977). The existence of a benthopelagic fauna in the deep sea. Deep Sra Res., Suppl. 24: 483-497

Mauchline, J. (1972). Assessing similarity between samples of plankton. J. mar biol. Ass. India 14: 2041

Mauchline, J. (1989). Pelagic investigations. Rep. Scott. Mar. Biol. Ass. 1988/89: 13-14

Mauchline, J. (1990). Aspects of production in a marginal oceanic region, the Rockall Trough, northeastern Atlantic Ocean. CRC crit. Rev. aquat. Sci. 2: 167-183

Mauchline, J., Fisher, L. R. (1969). The biology of euphausiids. Adv. mar Biol. 7. 1-454

Mauchline, J., Gordon, J. D. M. (1983). Diets of clupeoid, stomiatoid and salmonoid fish of the Rockall Trough, northeastern Atlantic Ocean. Mar. Biol. 77. 67-78

Mauchline, J., Gordon, J. D. M. (1984a). Diets and bathymetric distribution of the macrourid fish of the Rockall Trough, northeastern Atlantic Ocean. Mar. Biol. 81: 107-121

Mauchline, J., Gordon, J. D. M. (1984b). Feeding and bathymetric distribution of the gadoid and morid fish of the Rockall Trough. J. mar. biol. Ass. U.K. 64: 657-665

Mauchline, J., Gordon, J. D. M. (1985). Trophic diversity in deep-sea fish. J. Fish Biol. 26: 527-535

Mauchline, J., Gordon, J. D. M. (1986). Foraging strategies of deep-sea fish. Mar Ecol. Prog. Ser 27. 227-238

Mauchline, J., Harvey, P. F. (1983). The Scyphomedusae of the Rockall Trough, northeastern Atlantic Ocean. J. Plankton Res. 5: 881-890

Merrett, N. R. (1986). Biogeography and the oceanic rim: a poorly known zone of ichthyofaunal interaction. UNESCO Tech. Pap. mar. Sci. 49: 201-209

Merrett, N. R., Badcock, J., Ehrich, S., Hulley, P. A. (1986). Preliminary observations on the near-bottom ichthyofauna of the Rockall Trough: a contemporaneous investigation using commercial-sized midwater and demersal trawls to $100 \mathrm{~m}$ depth. Proc. R. Soc. Edinb. 88B: 312-314

This article was submitted to the editor
Pearcy, W. G. (1984). Some distributional features of mesopelagic fishes off Oregon. J. mar Res. 22: 93-102

Rice, A. L., Billett, D. S. M., Fry, J., John, A. W. G., Lampitt. R. S., Mantoura, R. F. C., Morris, R. J. (1986). Seasonal deposition of phytodetritus to the deep-sea floor Proc. $R$ Soc. Edinb. 88B: 265-279

Roe, H. S. J., Shale, D. M. (1979). A new multiple rectangular midwater trawl (RMT $1+8 \mathrm{M}$ ) and some modifications to the Institute of Oceanographic Sciences RMT $1+8$. Mar Biol. 50: 283-288

Roe, H. S. J., Baker, A. de C., Carson, R. M., Wild, R., Shale, D. M. (1980). Behaviour of the Institute of Oceanographic Sciences rectangular midwater trawls: theoretical aspects and experimental observations. Mar Biol. 56: 247-269

Smith, C. R. (1985). Food for the deep sea: utilization, dispersal and flux of nekton falls at the Santa Catalina Basin floor Deep Sea Res. 32: 417-442

Stockton, W. L., DeLaca, T. E. (1982). Food falls in the deepsea: occurrence, quality and significance. Deep Sea Res. 29: $157-169$

Thiel, J., Pfannkuche, P., Schriever, G., Lochte, K., Gooday, A. L., Hemelben, Ch., Mantoura, R. F. G., Turley, C. M., Patching, J. W., Reimann, F. (1990). Phytodetritus on the deep-sea floor in a central oceanic region of the NE Atlantic. Biol. Oceanogr 6: 203-239

Wishner, K. F. (1980a). The biomass of the deep-sea benthopelagic plankton. Deep Sea Res. 27. 203-216

Wishner, K. F. (1980b). Near-bottom sound scatterers in the Ecuador Trench. Deep Sea Res. 27: 217-223

Wishner, K. F. (1980c). Aspects of the community ecology of deep-sea benthopelagic plankton, with special attention to gymnopleid copepods. Mar Biol. 60: 179-187

Wishner, K. F., Gowing, M. M. (1987). In situ filtering and ingestion rates of deep-sea benthic boundary-layer zooplankton in the Santa Catalina Basin. Mar. Biol. 94: 357-366

Wishner, K. F., Meise-Munns, C. J. (1984). In situ grazing of deep-sea benthic boundary-layer zooplankton. Mar. Biol. $84: 65-74$

Manuscript irst received: February 14, 1991

Revised version accepted: May 8, 1991 